\title{
Radiographic assessment of the quality of dental restorations and their relationship with periodontal radiographic changes
}

João Henrique Parise Fortes ${ }^{a}$, Felipe Guarda Dallavilla ${ }^{a}$, Camila Tirapelli ${ }^{a}$, Plauto Christopher Aranha Watanabe ${ }^{a}$, Ana Caroline Ramos Brito ${ }^{b}$, Christiano de Oliveira-Santos $^{a}$

\begin{abstract}
INTRODUCTION: The quality of dental restorations can be directly related to the maintenance of periodontal health. Particularly in relation to the contour of interproximal restorations, radiographs allow the assessment of possible excess or lack of proximal contact of restorative materials.

OBJECTIVE: To evaluate the frequency of adequate and inadequate restorations, the type of restorative material and the relationship of these parameters with periodontal alterations.

METHODS: One hundred digital panoramic radiographs were evaluated, with interproximal restorations being observed on these examinations, classifying them according to the material used and the quality of interproximal restoration and the presence of periodontal alterations. The possible correlation between these parameters was evaluated.

RESULTS: The frequency of adequate restorations was $48 \%$ of restored proximal surfaces. Among the inadequate restorations, $46.2 \%$ and $53.8 \%$ were over-contour and lack of proximal contact, respectively. The restorations were metallic in $64 \%$ of cases.

CONCLUSION: Over-contour were more common among metal restorations and lack of proximal contact was more frequent among non-metal restorations. The presence of restorations was associated with increased prevalence of periodontal alterations.
\end{abstract}

Keywords: Panoramic radiograph; Alveolar bone loss; Permanent dental restoration; Dental restoration failure

\section{Avaliação radiográfica da qualidade de restaurações dentárias e sua relação com alterações radiográficas periodontais}

\section{RESUMO}

INTRODUÇÃO: A qualidade das restaurações dentárias pode estar diretamente relacionada à manutenção da saúde periodontal. Particularmente, em relação ao contorno das restaurações proximais, o exame radiográfico permite avaliar a ocorrência de excessos ou ausência de ponto de contato do material restaurador.

OBJETIVO: Avaliar a qualidade das restaurações dentárias, o tipo de material restaurador e a relação dessas observações com alterações periodontais.

MÉTODOS: Cem radiografias digitais panorâmicas foram avaliadas, com foco na observação das restaurações proximais, classificando-as de acordo com o material utilizado, a qualidade da restauração e a presença de alterações periodontais. Foi avaliada a possível correlação entre os parâmetros.

RESULTADOS: A frequência de restaurações adequadas, nas superfícies proximais, foi de $48 \%$. Ao se considerar o percentual de restaurações insatisfatórias, $46,2 \%$ e 53,8\% apresentavam sobrecontorno e ausência de contato proximal, respectivamente. As restaurações eram metálicas em $64 \%$ dos casos.

CONCLUSÃO: A ocorrência de sobrecontorno foi mais prevalente entre as restaurações metálicas e a ausência de contato proximal foi mais frequente quando da existência de restaurações em material não-metálico. A presença de restaurações proximais estava associada ao aumento de alterações periodontais.

Palavras-chave: Radiografia panorâmica; Perda de osso alveolar; Restauração dental; Falha restauradora a Universidade de São Paulo, Faculdade de Odontologia de Ribeirão Preto - Ribeirão Preto, SP, Brazil

${ }^{b}$ Universidade de Campinas, Faculdade de Odontologia de Piracicaba - Piracicaba, SP, Brazil 


\section{INTRODUCTION}

Dental restorations are intended to reestablish the form, function and aesthetics of the tooth. Restorative Dentistry has a close relationship with periodontal health. As a rule, all restorative procedures should only be performed after examining clinical and radiographic periodontal structures. Untreated periodontal disease can compromise the success of restorative therapy and inadequate restoration can lead to an iatrogenic effect on periodontal tissues [1-3].

The technical quality of dental restorations is a crucial factor in maintaining the oral health [4-9]. Defective restorations are associated with a higher prevalence of secondary caries [4] and periapical lesions [5, 6, 8, 9]. The restorations with irregular contour are also related to higher incidence of periodontal problems [8].

The radiographs are essential diagnostic tools in dentistry, once they allow assessing the quality of dental restorations, especially in regions that cannot be seen clinically, such as the proximal surfaces $[11,12]$ and the tooth tissue underlying the restoration. Panoramic, periapical and interproximal radiographs are employed isolated or in association, in order to result in final diagnosis. The panoramic radiograph, although presents disadvantages such as the image resolution lower than intraoral radiographs and greater geometric distortion, provides a great coverage of the bone and dental tissues, using a relatively low dose of radiation and fast technique, with more comfort to the patient [11-13].

The quality of coronary restorations is not associated only with maintaining the masticatory function and the stomatognathic complex, but they are also related to the periodontal health [8]. The contour of the restorations is a determinant factor of periodontal health and requires attention of the dentists. It is known that the greater the number of restorations in a patient, the greater the potential for adverse effects on periodontal health, especially in the presence of inadequate restorations $[8,10]$.

The aim in this study was to evaluate, through a sample of digital panoramic radiography images, the frequency of appropriate (proper interproximal contour) and inappropriate (showing lack or excess of interproximal restorative material) dental restorations, frequency of the restorative material (metallic or non-metallic) and to verify a possible association of these parameters with radiographic alterations of the periodontium.

\section{Hypotheses evaluated}

The frequency of defective restorations is different between the metallic and nonmetallic materials; defective restorations are more associated with periodontal changes; restorations with over-contour have different frequency of periodontal changes of the restorations with sub-contour; the frequency of restorations with over-contour is different from the restorations with sub-contour between metallic and nonmetallic materials.

\section{METHODS}

This was a retrospective study, using digital panoramic radiographs from a Brazilian School of Dentistry, obtained between August and October 2011, and approved by the Ethics Committee on Human Research under the registration number 404.454.

Data such as age and gender were not considered as a criterion of exclusion or inclusion. Only radiographs of excellent technical quality and those where patients had posterior teeth with restorations in proximal surfaces were included in this study.

Two calibrated radiologists evaluated the images in a room suitable for radiographic interpretation. At each session, a maximum of 10 radiographs were analyzed, with one week interval between assessments. The parameters of brightness and contrast of images, as well as application of magnification (zoom) could have been changed freely by the operator, for a better viewing the structures of interest.

The posterior teeth with direct or indirect dental restorations in proximal surfaces were selected and evaluated according to the following parameters:

- Interproximal restoration (Figure 1): absent, appropriate, with over-contour, with sub-contour, non-displayed;

- Restorative material: metallic or non-metallic;

- Secondary caries and other conditions predisposing to periodontal alterations: presence or absence of radiographic signs of caries lesions underlying the restoration and / or dental calculus, fractures, etc;

- Proximal surface: presence or absence of proximal contact between the surfaces evaluated;

- Periodontal Alterations: presence or absence of radiographic signs of periodontal alterations (significant increase in pericementary space in the cervical third of the root, alveolar cortical discontinuity, resorption of alveolar bone crest). In cases of generalized periodontal alterations, it was recorded as "presence" only when bone loss was greater than in other regions.

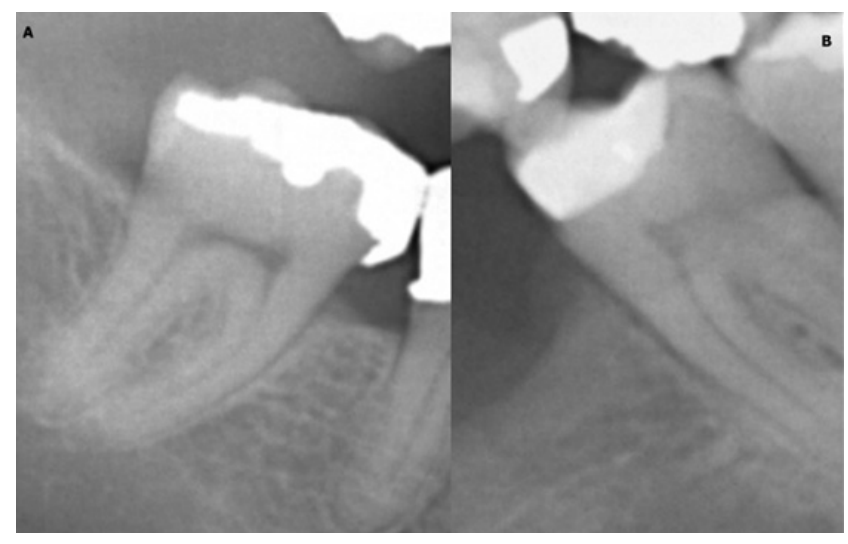

Figure 1. cropped panoramic radiograph demonstrating examples of inadequate restoration: (A) over-contour on the mesial of the lower molar; (B) sub-contour on the mesial of the lower molar 
The frequency of restorative treatments considered appropriate or inappropriate (over-contour or sub-contour) from the point of view of the proximal contour, the restorative material used and the frequency of periodontal alterations observed radiographically were presented through descriptive statistics.

For the evaluation of the effect of proximal restoration with periodontal bone loss, it was excluded the free proximal surfaces, with the presence of caries and/or the presence of other conditions. The agreement between evaluators was calculated using the kappa value. Possible associations between the parameters evaluated were analyzed using the chi-square test.

\section{RESULTS}

After initial analysis of 237 exams, the inclusion and exclusion criteria were applied and 100 panoramic radiographs were selected. A total of 1026 proximal surfaces related to missing teeth were excluded from the analysis.
Them the sample was included 2174 proximal surfaces. The presence and quality of proximal restorations; their quality toward the group of teeth, the type of restorative material and the presence/absence of periodontal alterations are shown in Table 1.

The restored surfaces have presented metallic material in $64 \%$ of cases and $36 \%$ had a non-metallic material. The restorations were appropriate in $44.4 \%$ of metallic restorations and in $55.6 \%$ of the non-metallic. It was observed secondary caries in $11 \%$ of proximal restorations and other conditions (dental calculus, fractures, etc.) in 14\%. Surfaces without proximal contact (free surfaces) constituted $15 \%$ of the sample. Periodontal alterations were present in $28 \%$ of cases.

Regarding the mesial or distal location of the proximal surfaces, restorations were appropriate in $46.9 \%$ of mesial surfaces and $45.8 \%$ of the distal surfaces; over-contour was presented in $31.7 \%$ of mesial surfaces and $25.3 \%$ of the distal surfaces; and sub-contour was observed in $21.4 \%$ of mesial surfaces and $28.9 \%$ of the distal surfaces.

Table 1. Frequency of proximal surfaces according to the different variables

\begin{tabular}{|c|c|c|}
\hline Proximal surfaces regarding the presence of restorations and its quality & \multicolumn{2}{|c|}{ n (\%) } \\
\hline Without Restoration & \multicolumn{2}{|c|}{$1436(66.1)$} \\
\hline Non-Viewed & \multicolumn{2}{|c|}{$174(8)$} \\
\hline Appropriate Restoration & \multicolumn{2}{|c|}{$261(12)$} \\
\hline Sub-Contour & \multicolumn{2}{|c|}{$151(6.9)$} \\
\hline Over-Contour & \multicolumn{2}{|c|}{$152(7)$} \\
\hline Total & \multicolumn{2}{|c|}{$2174(100)$} \\
\hline Quality of proximal restorations according to the group of teeth & $\begin{array}{c}\mathrm{PM} \\
\mathrm{n}(\%)\end{array}$ & $\begin{array}{c}M \\
\mathrm{n}(\%)\end{array}$ \\
\hline Appropriate Restoration & $90(34.5)$ & $171(65.5)$ \\
\hline Sub-Contour & $33(21.9)$ & $118(78.1)$ \\
\hline Over-Contour & $54(35.5)$ & $98(64.5)$ \\
\hline Total & $177(100)$ & $387(100)$ \\
\hline Quality of proximal restorations according to the restorative material & $\begin{array}{c}\text { Non-metallic } \\
\mathrm{n}(\%)\end{array}$ & $\begin{array}{l}\text { Metallic } \\
\mathrm{n}(\%)\end{array}$ \\
\hline Appropriate Restoration & $145(55.6)$ & $116(44.4)$ \\
\hline Sub-Contour & $99(65.6)$ & $52(34.4)$ \\
\hline Over-Contour & $130(85.5)$ & $22(14.5)$ \\
\hline Total & $374(100)$ & $190(100)$ \\
\hline Surfaces with proximal restorations related to the presence or absence of periodontal alterations & $\begin{array}{c}\text { Absent } \\
\text { n (\%) }\end{array}$ & $\begin{array}{c}\text { Present } \\
\mathrm{n}(\%)\end{array}$ \\
\hline Appropriate Restoration & $187(71.8)$ & $74(28.2)$ \\
\hline Sub-Contour & $107(71.2)$ & $44(28.8)$ \\
\hline Over-Contour & $109(72.2)$ & $43(27.8)$ \\
\hline Total & 403 & 161 \\
\hline Metallic Material & $270(72.2)$ & $104(27.8)$ \\
\hline Non-Metallic Material & $133(70.0)$ & $57(30.0)$ \\
\hline Total & 403 & 161 \\
\hline
\end{tabular}

PM: premolar; M: molar. 
The quality of restoration was evaluated according to the type of teeth among the premolars and molars, upper and lower, as is shown in Figure 2.

The relationship between the presence of periodontal alterations and parameters of the proximal restorations were evaluated. Surfaces with proximal restoration presented periodontal alterations in $29.4 \%$ of cases, while the surfaces without restoration had periodontal alterations in $24.1 \%$ of cases. This difference was statistically significant (Table 2 ). There was no statistically significant difference regarding the presence of periodontal alterations and these parameters (Table 3).

The relationship between the restorative material (metallic or non-metallic) and parameters of proximal restorations were also evaluated. The differences were significant regarding the distribution of the restoration qualities (adequate or inadequate, over-contour or subcontour), according to the restorative material, metallic and non-metallic, for both cases (Table 3).

The inter-observer agreement showed kappa indexes from moderate to excellent (quality of interproximal restoration $=0.775$; restorative material $=0.891$; secondary caries $=0.604$; other conditions $=1.0$; free surface $=1.0$ ).

\section{DISCUSSION}

The present study revealed that among the restorations analyzed, most were inadequate, and lower molars showed the highest frequency of surfaces with restorations with over/sub contour. The difficulty in adapting metal matrix and polyester strips on molars may be related to this result. Over-contour was more frequent at mesial surfaces, while at the distal aspect, the sub-contour prevailed.

The molars surfaces have shown more restorations than the premolars, which may be related to long presence of this teeth in the oral cavity and its posterior position, which can difficult a proper cleaning. The upper premolars showed more proximal restorations that the lower premolars. Among the surfaces of premolars, sub-contour was more frequent, while among the surfaces of the molars, over-contour prevailed. This may also be associated with technical difficulties in adapting the matrices.

The presence of periodontal alterations was observed in $28 \%$ of proximal surfaces. This result does not mean that this was the real frequency of areas with periodontal alterations, since in this study, most of the patients presented generalized periodontal bone loss. Only when the periodontal bone loss

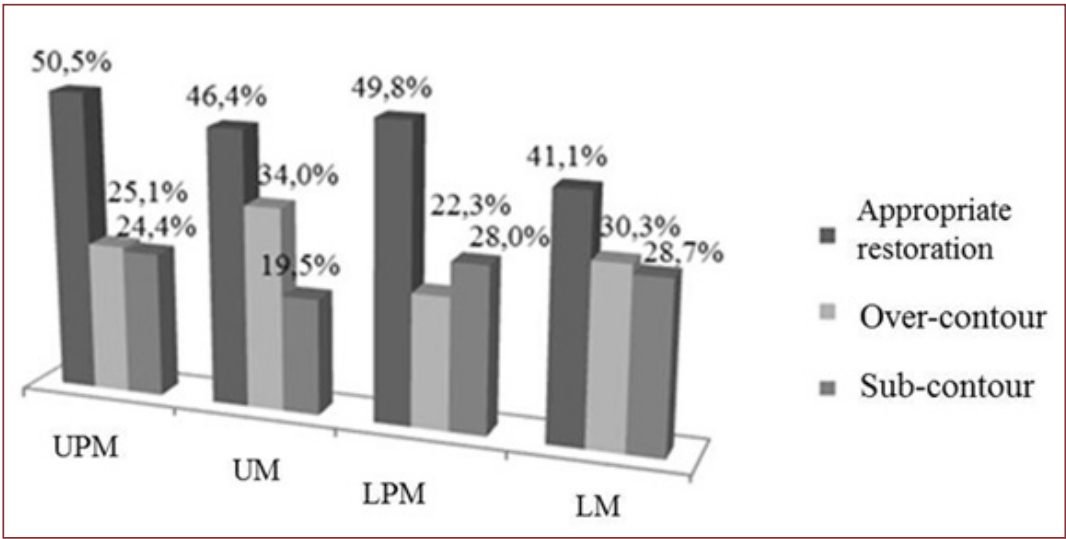

Figure 2. Frequency, in percentage, quality of restorations in relation to the type of tooth among premolars and molars, upper and lower

Table 2. Qui-square test results, comparing characteristics of proximal restorations with periodontal alteration.

\begin{tabular}{lcc}
\hline Parameter evaluated according to the presence of periodontal alteration & Qui-square & 3.98 \\
Presence of proximal restoration & 0.10 & $0.046^{*}$ \\
Quality of restoration (adequate or inadequate) & 0.02 & 0.752 \\
Type of inadequation of restoration (over-contour/sub-contour) & 0.06 & 0.893 \\
Restorative material (metallic/non-metallic) & 0.808 \\
\hline
\end{tabular}

$* p<0.05$

Table 3. Qui-square test results, comparing characteristics of proximal restorations with restorative material.

\begin{tabular}{lcc}
\hline Parameter evaluated according to the restorative material & Qui-square & 7.27 \\
Quality of restoration (adequate or inadequate) & 3.88 & $0.007^{*}$ \\
Quality of restoration (over-contour/sub-contour) & $049^{\star}$ \\
\hline
\end{tabular}

\footnotetext{
$* p<0.05$
} 
near to the surface analyzed was higher than in other regions, it was registered as "presence of periodontal alteration".

Periodontal alterations may be justified by the presence of inadequate restorations (with over/sub contour), once failure in finishing the margins between the tooth and the restorative material (generating excess or absence) promote retention and plaque buildup, which can result in periodontal disease $[7,10]$. Furthermore, restorations that have marginal failure may have more secondary caries than e teeth with adequate restorations [5]. Dumitrescu et al. (2009) [14] showed that the presence of caries causes greater periodontal alterations than in restored tooth and the presence of restoration causes greater periodontal changes than in healthy tooth. So, the quality of the proximal tooth surface influences the health of the adjacent periodontium [15]. According to Farias et al. (2008) [16] the only variable considered in the radiographic examination that showed significant association with the occurrence of periodontal radiographic alteration was the lack of proximal contact.

The proximal surfaces of premolars were the most difficult in viewing, and their contours were not visualized in $17.3 \%$ of cases. This is in accordance with the technical limitation of the panoramic radiograph, which due to the geometrical projection, lead to an image distortion and overlapping of the crowns on the proximal surfaces, especially in the premolar region $[12,17]$.

In the present study, we used panoramic radiographs, which enable great coverage of the bone and dental tissues with relatively low dose of radiation. This is also a fast and convenient technique, but in return, leads to structural overlays, has image resolution lower than intraoral radiographs and provides greater distortion geometry $[12,17,18]$. The large number of non-visualized proximal contours and the difficulty in classifying the presence of periodontal alteration can be attributed to the panoramic radiograph. As reported by Farman (2002) [18], the resolution of a panoramic radiograph is lower than an intraoral radiography. However, other studies have shown that panoramic radiograph are equal to intraoral radiographs in detecting occlusal caries [19], and the sensitivity and specificity of bitewing radiographs in relation to dental caries detection is poor [20], which would justify the use of panoramic radiographs in this study. Besides, the panoramic radiograph is the most requested radiographic technique in health care and it is used as a form of screening [21-26]. Therefore, these images were found in large quantities in our files, which contributed to their choice for this study.

The only parameter evaluated that showed statistically significant association with periodontal alteration was the presence of proximal restoration $(\mathrm{p}<0.05)$. Other parameters related to the restoration (adequate or inadequate, over/sub contour, metallic/non-metallic materials) were not associated with periodontal alterations. These finds disagree with those found in the literature and can demonstrate methodological failure in the present study.

Some relevant risk factors for the establishment of periodontal disease, such as drug use [16], smoking [16,27] and diabetes [28] were not known in this study. Most patients showed generalized periodontitis and the periodontal alteration was considered only in sites which were discrepant in relation to others.

In this study, the restorations with non-metallic materials showed a higher percentage of suitable contours that those with metallic material. When the restorations were inadequate, in most cases it was observed over-contour in metallic restorations and sub-contour in non-metallic ones. Non-metallic materials, such as composite resin, are more likely to open proximal contacts (sub-contour) due to the absence of condensation on restorative technique [29].

Results of radiographic studies of caries and marginal defects have shown that there is a higher percentage of secondary caries and marginal defects in composite restorations than amalgam, which may be related to a lower level of radiopacity of resin, and may be associated with an increase in detecting caries and adjacent defects to the restorations [30].

\section{CONCLUSION}

Within the limitations of this study, particularly related to the use of panoramic radiographs to assess the quality of restored proximal surfaces, the presence of proximal restorations was associated with higher prevalence of periodontal alterations; over-contour were more common among metal restorations and sub-contour were more frequent among non-metal restorations.

\section{REFERENCES}

1. Valderhaug J, Birkeland JM. Periodontal conditions in patients 5 years following insertion of fixed prostheses. Pocket depth and loss of attachment. J Oral Rehabil. 1976;3:237-43. https://doi.org/10.1111/j.1365-2842.1976. tb00949.x

2. Oliveira Júnior L. Guia prático de dentística e prótese dentária. Goiânia: Edição do autor; 2007

3. Baratieri LN. Odontologia Restauradora - fundamentos e possibilidades. São Paulo: Santos; 2015.

4. Mjör I a, Qvist V. Marginal failures of amalgam and composite restorations J Dent. 1997;25:25-30. https://doi.org/10.1016/S0300-5712(95)00119-0

5. Kirkevang LL, Ørstavik D, Hörsted-Bindslev P, Wenzel A. Periapical status and quality of root fillings and coronal restorations in a Danish population. Int Endod J. 2000;33:509-15. https://doi.org/10.1046/j.13652591.2000.00381.x

6. Hommez GMG, Coppens CRM, De Moor RJG. Periapical health related to the quality of coronal restorations and root fillings. Int Endod $\mathrm{J}$. 2002;35:680-9. https://doi.org/10.1046/j.1365-2591.2002.00546.x

7. Matthews DC, Tabesh M. Detection of localized tooth-related factors that predispose to periodontal infections. Periodontol 2000. 2004;34:136-50. https://doi.org/10.1046/j.0906-6713.2003.003429.x

8. Siqueira JF, Rôças IN, Alves FRF, Campos LC. Periradicular status related to the quality of coronal restorations and root canal fillings in a Brazilian population. Oral Surgery, Oral Med Oral Pathol Oral Radiol Endodontology. 2005;100:369-74. https://doi.org/10.1016/j.tripleo.2005.03.029

9. Gencoglu N, Pekiner FN, Gumru B, Helvacioglu D. Periapical status and quality of root fillings and coronal restorations in an adult Turkish subpopulation. Eur J Dent. 2010;4:17-22.

10. Block PL. Restorative margins and periodontal health: a new look at an old perspective. J Prosthet Dent. 1987;57:683-9. https://doi.org/10.1016/00223913(87)90363-5

11. Akkaya N, Kansu Ö, Kansu H, Çağirankaya L, Arslan U. Comparing the accuracy of panoramic and intraoral radiography in the diagnosis of proximal caries. Dentomaxillofacial Radiol. 2006;35:170-4. https://doi. org/10.1259/dmfr/26750940 
12. White SC, Pharoah MJ. Radiologia Oral: Princípios e Interpretação. Rio de Janeiro: Elsevier; 2015

13. Rushton VE, Horner K. The use of panoramic radiology in dental practice. J Dent. 1996;24:185-201. https://doi.org/10.1016/0300-5712(95) 00055-0

14. Dumitrescu AL, Teslaru S, Mocanu V. The influence of restorations on periodontal health. Rev Med Chir Soc Med Nat lasi. 2009;113:575-8.

15. Yusof Z. Proximal tooth surface quality and periodontal status. J Oral Rehabil. 1991;18:95-102. https://doi.org/10.1111/j.1365-2842.1991. tb00035.x

16. Farias B de C, Barros FC, Araújo AC da S, Gusmão ES, Almeida ECB de, Cimões R. Avaliação da condição periodontal adjacente a superfícies proximais restauradas em material resinoso, comparativamente a superfícies não restauradas. RGO (Porto Alegre). 2008:56:245-51.

17. Kamburoğlu K, Kolsuz E, Murat S, Yüksel S, Özen T. Proximal caries detection accuracy using intraoral bitewing radiography, extraoral bitewing radiography and panoramic radiography. Dentomaxillofacial Radiol. 2012 41:450-9. https://doi.org/10.1259/dmfr/30526171

18. Farman $A G$. There are good reasons for selecting panoramic radiography to replace the intraoral full-mouth series. Oral Surg Oral Med Oral Pathol Oral Radiol Endod. 2002;94:653-4. https://doi.org/10.1067/ moe.2002.129766

19. Thomas MF, Ricketts DN, Wilson RF. Occlusal caries diagnosis in mola teeth from bitewing and panoramic radiographs. Prim Dent Care. 2001; 8:63-9. https://doi.org/10.1308/135576101322647908

20. Ricketts DN, Whaites EJ, Kidd EA, Brown JE, Wilson RF. An evaluation of the diagnostic yield from bitewing radiographs of small approximal and occlusal carious lesions in a low prevalence sample in vitro using different film types and speeds. Br Dent J. 1997;182:51-8. https://doi. org/10.1038/sj.bdj. 4809298

21. Moura LB, Blasco MAP, Damian MF. Exames radiográficos solicitados no atendimento inicial de pacientes em uma Faculdade de Odontologia brasileira. Rev Odontol da UNESP. 2014;43:252-7. https://doi.org/10.1590/ rou. 2014.046
22. Martínez Beneyto Y, Alcaráz Banos M, Pérez Lajarin L, Rushton VE. Clinical justification of dental radiology in adult patients: a review of the literature. Med Oral Patol Oral Cir Bucal. 2007:12:244-51.

23. Shahab S, Kavosi a., Nazarinia H, Mehralizadeh S, Mohammadpour M. Emami M. Compliance of Iranian dentists with safety standards of oral radiology. Dentomaxillofacial Radiol. 2012;41:159-64. https://doi. org/10.1259/dmfr/29207955

24. Kantor ML. Radiographic examination of comprehensive care patients in U.S. and Canadian dental schools. Oral Surg Oral Med Oral Pathol. 1988 65:778-81. https://doi.org/10.1016/0030-4220(88)90029-1

25. Rushton VE, Horner K, Worthington $\mathrm{H}$ V. Routine panoramic radiography of new adult patients in general dental practice: Relevance of diagnostic yield to treatment and identification of radiographic selection criteria. Oral Surg Oral Med Oral Pathol Oral Radiol Endod. 2002;93:488-95. https:// doi.org/10.1067/moe.2002.121994

26. Bohay RN, Stephens RG, Kogon SL. Survey of radiographic practices of general dentists for the dentate adult patient. Oral Surg Oral Med Oral Pathol Oral Radiol Endod. 1995;79:526-31. https://doi.org/10.1016/ S1079-2104(05)80140-4

27. Lins RDAU, Alves RD, Lucena KCR, Pequeno MT. O relevante papel do fumo como fator modificador da resposta imune na doença periodontal. Rev bras odontol. 2005;62:128-31.

28. Peruzzo DC, Benatti BB, Antunes IB, Andersen ML, Sallum E a., Casati MZ, et al. Chronic Stress May Modulate Periodontal Disease: A Study in Rats. J Periodontol. 2008;79:697-704. https://doi.org/10.1902/jop.2008.070369

29. Bastos MTAA, Lovadino JR, Almeida JV de, Martins LRM, Navarro MF de L. Resinas compostas em dentes posteriores. Rev odontol Univ Säo Paulo. 1987;1:42-5

30. Tveit AB, Espelid I. Radiographic diagnosis of caries and marginal defects in connection with radiopaque composite fillings. Dent Mater. 1986;2 159-62. https://doi.org/10.1016/S0109-5641(86)80027-6 